\title{
AN ANALYSIS OF CONSUMER INTEREST LEVEL DATA FOR ONLINE HEALTH INFORMATION IN THE EARLY STAGES OF THE COVID-19 PANDEMIC
}

\author{
David C. Wyld \\ Department of Management and Business Administration, Southeastern Louisiana \\ University, Hammond, Louisiana
}

\begin{abstract}
This paper takes a unique look at the online consumer interest in health information and products during a unique moment - the COVID-19/coronavirus pandemic of 2020. The present research examines Glimpse's data on consumer interest levels in a wide variety of health topics, products, and services during March 2020, the month when the COVID-19 outbreak brought much of American life and the U.S. economy to a standstill. Through an analysis of the trend data on the health information sought out online during this critical period, the author provides insights into the consumer behavior demonstrated by Americans in light of the pandemic.
\end{abstract}

\section{KEYWORDS}

Marketing, Health, Health Information, Personal Health, Wellness, Online, Search, Consumers, Consumer Behavior, Internet, Web, Pandemic

\section{INTRODUCTION}

What did we search for online in regards to health info, medicine, treatment options and yes, products that may - or may not - really help us in the midst of the COVID-19/coronavirus pandemic? [1] In short, Americans - scared, quarantined, and with plenty of time on their hands used the Internet a whole lot (in the best academic term this expert can muster) while they began to face life in isolation and lockdown [2] in the face of this epidemiological Black Swan event! [3]

In this article, we will look specifically at the health aspects of our online lives during this tumultuous period. We will examine Web trends during the month of March 2020 - the month when the coronavirus unfortunately became the story of most of our lifetimes and a monumental challenge for the entire country. [4] And yes, this analysis will reveal a great deal about what Americans were worried about, thinking about, and searching out as our country and ourselves came to grips with the worst pandemic in over a century.

\section{RESEARCH METHODS}

This research draws upon data from Glimpse, New York City-based firm. This startup company aggregates info from all of our online activity to discover underlying trends regarding products, companies, and industries. Glimpse's key metric is what they term to be consumer interest levels, which is based on the company's proprietary analysis of "hundreds of millions of consumer behavior signals from across the web." [5] 
And so in looking at Glimpse's statistical analysis of consumer interest levels in various products during March 2020, the month when the COVID-19/coronavirus pandemic took off in the United States [6] and brought-on both self- and state-imposed stay-at-home orders and quarantines [7], all of this reveals some very interesting insights into the mind and mood of Americans as we collectively encounter the fear, uncertainty, and economic disruption that has resulted from the widespread outbreak of this deadly disease and our efforts to isolate ourselves to "flatten the curve." [8]

In this research, we looked specifically at Glimpse's data on consumer interest levels across a variety of health topics in March 2020. [9] And as a reminder, as the disease outbreak worsened in mid-March in many areas of the country, most states implemented their stay-at-home orders sometime between the March 20th-April 1st period. Each chart below thus represents consumer interest levels data in that specific health subject for the entire month of March 2020. And as you look at these trends, do bear in mind that with the timing of the pandemic, the trends in the latter half of the month reflect the very real changes in consumer interest levels in these products/services among Americans as the pandemic caused people to shelter-in-place.

Here then are some of the more interesting health trends spotted in Glimpse's look at where America is - at least from a consumer perspective - in this most unsettled of times. We break down our analysis into two sections, examining the demonstrated consumer interest levels of Americans in March 2020 regarding first things that definitely help in the fight against the disease and then things that were largely "pandemic fad items" - rumored (or worse) to help prevent or even cure the coronavirus! The latter category includes both items ranging from laundry items to home medical equipment and then a whole range of supplements and pharmaceuticals - largely for off-label usage as a potential COVID-19 prevention/remedy - that saw interest from a very scared American public during the early stages of this pandemic.

\section{ANALYSIS}

For the sake of clarity, we will break our analysis into the following two categories:

1. Consumer Interest Levels in Topics That Might Prove Helpful in Fighting the Coronavirus

2. Consumer Interest Levels in Topics That Were Neutral or Potentially Harmful in Fighting the Coronavirus

\subsection{Consumer Interest Levels in Topics That Might Prove Helpful in Fighting the Coronavirus}

Within the "helpful" area, we will examine the Glimpse data on consumer interest levels in three specific areas. These are:

1. Telemedicine

2. Personal Protective Equipment (PPE)

3. Household Items.

\subsubsection{Telemedicine}

Telemedicine had been on the rise before March 2020. However, with patients fearing being exposed to the coronavirus and with doctors/clinics wanting to prevent infection of their patients and their staff, the pandemic seems to have created intense interest in all forms of telemedicine 
and telehealth. [10] According to the Centers for Medicare \& Medicaid Services (CMS), these terms, along with variants that may be employed by health plans, hospitals, etc., refer to any practice that results in "the exchange of medical information from one site to another through electronic communication to improve a patient's health." [11] Also, many hospitals and clinics have been directing patients who might believe they are experiencing mild to even moderate COVID-19 systems to use their telemedicine options rather than trying to visit their facilities. [12] This has been facilitated by states and health insurance plans changing rules and regulations regarding both patient access to telemedicine and physician/facility reimbursement provisions to encourage greater use of online interactions. [13] And likely, these changes will likely greatly accelerate the growing acceptance by patients, providers, and payers of telemedicine to reduce actual in-person patient care long beyond the immediate coronavirus outbreak. [14]

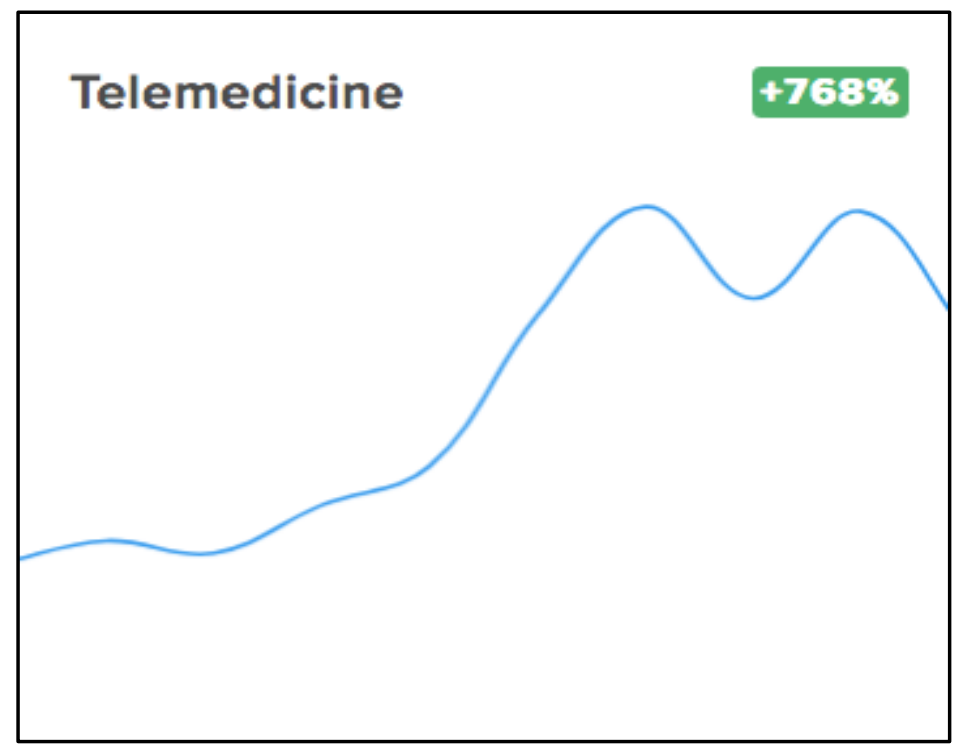

Figure 1. American Consumer Interest Levels in Telemedicine, March 2020

Thus, the fact that Glimpse's data showed an over $700 \%$ jump in consumer interest levels in telemedicine in March 2020 (see Figure 1: American Consumer Interest Levels in Telemedicine, March 2020). This figure is likely considerably lower than what the true interest in telemedicine was in the initial month of the COVID-19 pandemic in the U.S., as it did not capture online user's interest in any of the variant/synonymous terms, such as "telehealth," "virtual clinics," "online doctor visits." So, the true interest of Americans in being able to access medical care without going to a medical facility was likely far, far higher than even that demonstrated in the Glimpse consumer interest level findings.

\subsubsection{Personal Protective Equipment (PPE)}

One very unlikely trend that became readily apparent in examining Glimpse's March 2020 consumer interest level data was that undoubtedly, many, many individuals, hospitals, clinics, governments and companies were obviously looking all over the Web for the PPE (personal protective equipment) that quickly came to be in short supply in many areas of the country, endangering both medical care and medical workers. [15]

While the lack of PPE became a leading subject of intense media coverage and political debate as the COVID-19 outbreak worsened, [16] for those working in hospitals and for first responders, PPE became a matter of life and death for those employed in the health care sector. [17] As such, 
when their employers and institutions could not provide the items they needed, many doctors, nurses and other medical workers turned to the Internet for information and for acquiring their own PPE through many peer-to-peer and charitable networks that began to pitch in to help them. [18] Additionally, some Americans bought PPE items for their own personal use in an attempt to protect themselves from coronavirus exposure [19] - maybe beyond what they could have and should have for any home, work and/or social use outside the health care setting - no matter the circumstances.

The Glimpse data definitely shows intense consumer interest levels in PPE in March 2020 in regards to both isolation gowns (up 1154\%) (See Figure 2: American Consumer Interest Levels in Isolation Gowns, March 2020) and Tyvek suits (up 400\%) (Figure 3: American Consumer Interest Levels in Tyvek Suits, March 2020).

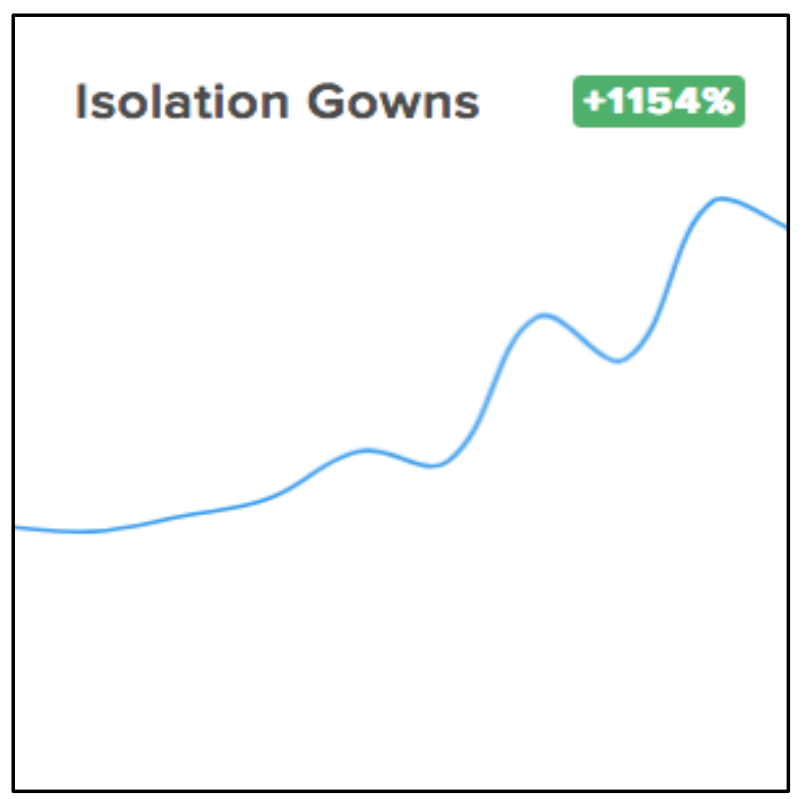

Figure 2. American Consumer Interest Levels in Isolation Gowns, March 2020

And yes, the consumer interest level in masks of all types and protective levels was not included in the Glimpse data for March 2020. However, given the intense shortages of the different levels of protective masks and the CDC's call for Americans to begin wearing masks

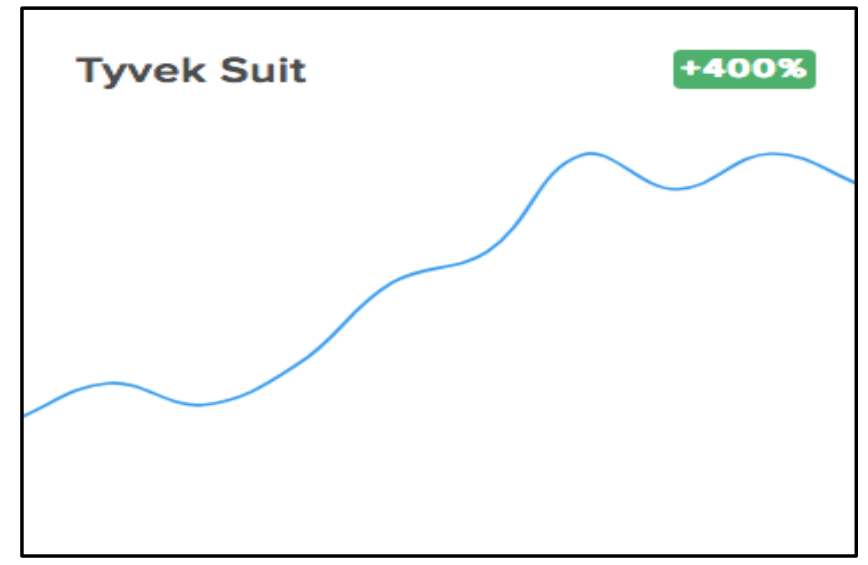

Figure 3. American Consumer Interest Levels in Tyvek Suits, March 2020 
in public places, [20] the consumer interest levels in masks of all types would likely far, far exceed that observed for the categories of PPE included in the available Glimpse data. And in the future, studies just focused on American's demand for facial protection masks - in a culture unlike those found in parts of Asia where mask-wearing is quite commonplace in public [21]will be needed from both marketing and public health perspectives.

\subsubsection{Household Items}

Glimpse's March 2020 consumer interest levels reveals that in the early stages of the pandemic, there was intense interest among Americans - as seen in their online activities - in taking steps that could help protect themselves and their family from the coronavirus. We all know about the craziness all across the country that surrounded hand sanitizers [22] - a topic that Glimpse did not include in their COVID-19 data under review in the present research, but which anecdotally might exceed anything seen in the categories they explored, owing to Americans' demonstrated intense online and offline interest in things that could possibly help in fighting the disease spread and in their potential infection with the virus. [23]

Because $60 \%$ alcohol solutions can kill the coronavirus, [24] alcohol prep pads - the same kind of wipe that healthcare workers use to clean your arm before giving you a shot or drawing blood actually do work in helping prevent the spread of the virus. Because the prep pads have $70 \%$ alcohol solutions on them, these items became popular to stock-up on to help prevent the spread of the virus. [25] Just as with the mad rush for hand sanitizers, [26] consumer interest here was in a product line that actually did prove to have value in helping prevent the spread of the coronavirus. And so yes, the once-sleepy product category of alcohol prep pads suddenly became a must have for many Americans, with consumer interest level in them rising by over $400 \%$ (see Figure 4: American Consumer Interest Levels in Alcohol Prep Pads, March 2020) in the early stages of the pandemic in the U.S. in March 2020.

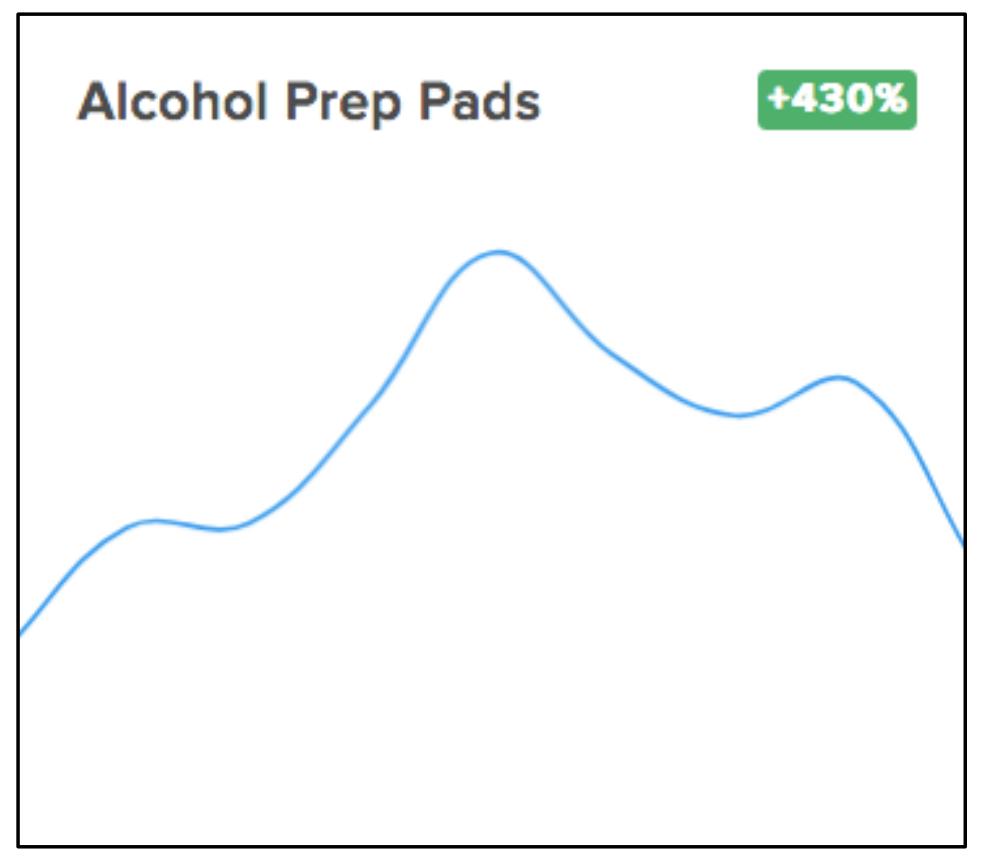

Figure 4. American Consumer Interest Levels in Alcohol Prep Pads, March 2020

There are, of course, a variety of other household items that can be utilized in the fight against the spread of the disease. This led to panic buying of everything from soaps to various disinfecting 
cleansers and yes, most of all, hand sanitizers. [27] One of the areas reviewed in the Glimpse data is laundry sanitizing, specifically how to kill the virus in the washing process. As you can see in the graphic below, consumer interest levels in laundry sanitizers rose by a whopping $1153 \%$ in the month under review (see Figure 5: American Consumer Interest Levels in Laundry Sanitizer, March 2020).

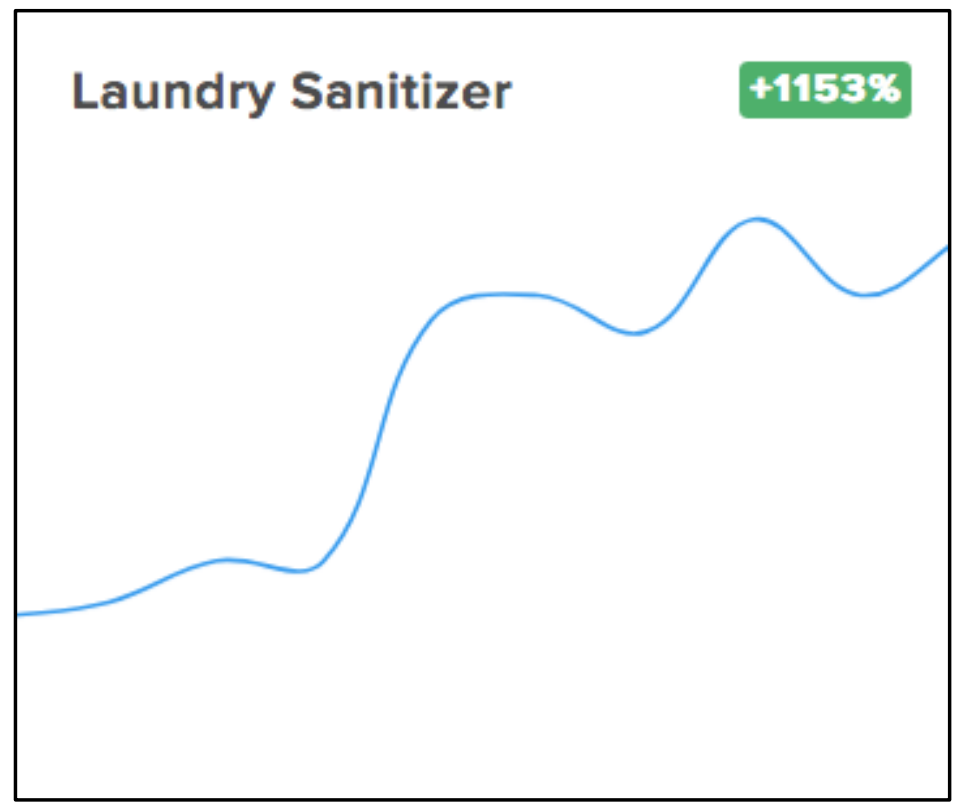

Figure 5. American Consumer Interest Levels in Laundry Sanitizer, March 2020

Now the science of just how long the coronavirus can exist on various fabrics and how best to actually "do" laundry to most effectively "kill" the virus is quite complex. [28], And yes, Americans showed a dramatic increase - well over tenfold - in their interest online in learning about laundry sanitizers and how to make use of them - hopefully properly - to fight the spread of the virus!

\subsection{Consumer Interest Levels in Topics That Were Neutral or Potentially Harmful in Fighting the Coronavirus}

One thing that we know about the Internet is that for all the value that it has as an information source, the counterargument is that the Web is fraught with not just disinformation, but plainly dangerous information! And that has certainly been the case in this instance, as not just Americans, but people around the globe have looked to online sources for answers to the dangers of the COVID-19 pandemic as perhaps no other scientific/medical event ever! At the same time though, this means that in the time of a great pandemic, there was also the need to deal with an "infodemic" of bad - and possibly dangerous, even deadly - misinformation. [29]

Want Exhibit A of misinformation on the coronavirus on the Internet? Let's start by looking at colloidal silver - a water solution in which small particles of silver are suspended - has long been used as a sterilization agent to be used only topically. Early in the coronavirus outbreak in the United States, televangelist Jim Bakker and others touted oral colloidal silver solutions as a way to prevent COVID-19, [30] only to be cracked down on by the FDA (Food and Drug Administration). [31] However, as Figure 6 (American Consumer Interest Levels in Colloidal Silver, March 2020) shows, this action did not entirely stop interest in ingesting colloidal 


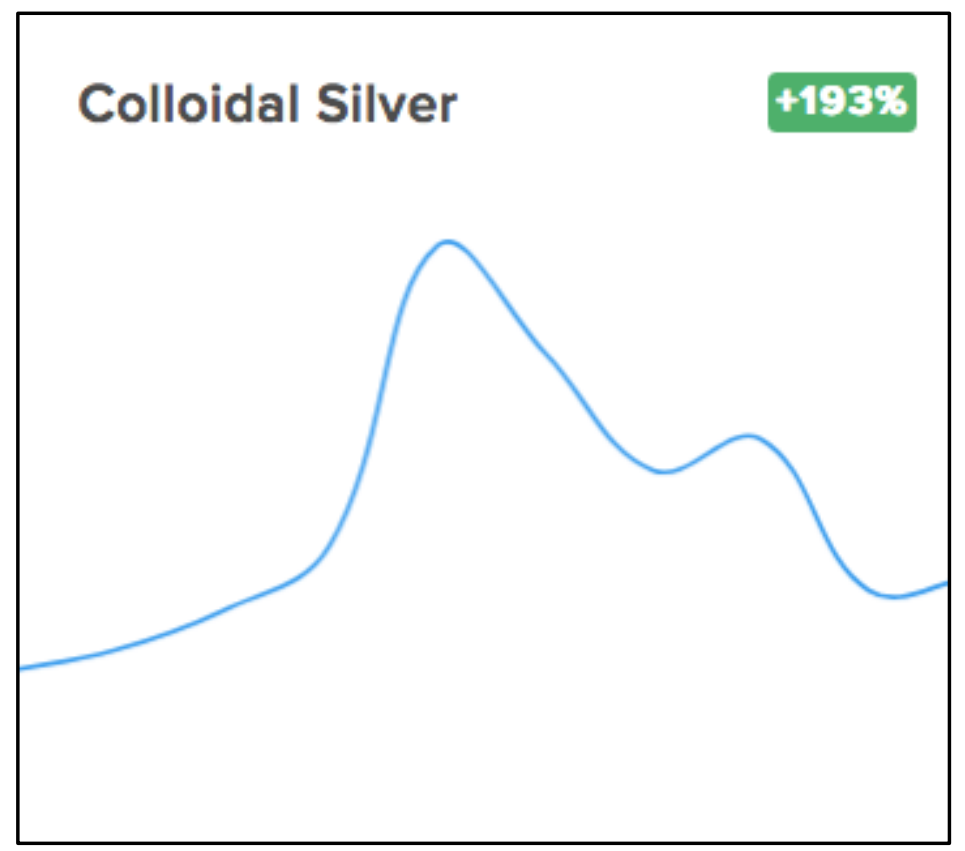

Figure 6. American Consumer Interest Levels in Colloidal Silver, March 2020

silver as a means of preventing the coronavirus, even though the NIH (National Institutes of Health) has issued a formal health warning that:

- Colloidal silver can cause serious side effects. The most common is argyria, a bluish-gray discoloration of the skin, which is usually permanent.

- Colloidal silver can also cause poor absorption of some drugs, such as certain antibiotics and thyroxine (used to treat thyroid deficiency).

- The FDA also warned in 1999 that colloidal silver isn't safe or effective for treating any disease or condition. [32]

In point of fact however, in spite of the government health warnings, consumer interest level in colloidal silver almost doubled during the month under review!

Now on the flip side, Americans also searched for a variety of items that may pose no harm to them, but might also have no real proven benefit in either preventing or fighting the coronavirus. Two such trends were revealed in the present analysis of the Glimpse data from March 2020. First, as can be seen in Figure 7 (American Consumer Interest Levels in Oximeters, March 2020) consumer interest levels in oximeters, a common portable home medical diagnostic device that measures oxygen saturation in the bloodstream, rose by over $200 \%$ in the early stages of the COVID-19 pandemic. The increased consumer interest in 


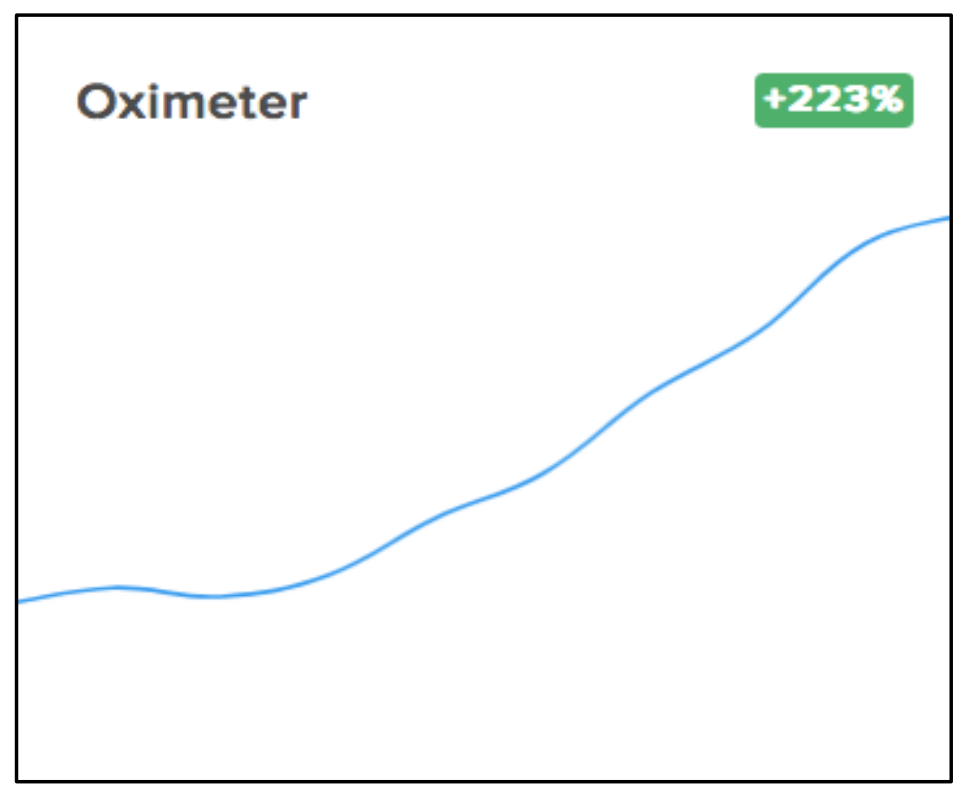

Figure 7. American Consumer Interest Levels in Oximeters, March 2020

these devices, mostly used by individuals with chronic respiratory conditions to monitor if their oxygen levels would be below normal, was attributed to media reports, including TV host Andy Cohen, who said that he used a pulse oximeter himself as he fought his own COVID-19 infection. [33] However, medical professionals warned in the media that for most people, these machines, while not causing harm, were ineffective in detecting possible COVID-19 infection. [34]

Likewise, during March 2020, consumer interest levels in ozone generating machines, commonly employed to remove strong odors from homes, office and other spaces, jumped by $224 \%$ (see Figure 8: American Consumer Interest Levels in Ozone Generators, March 2020)!

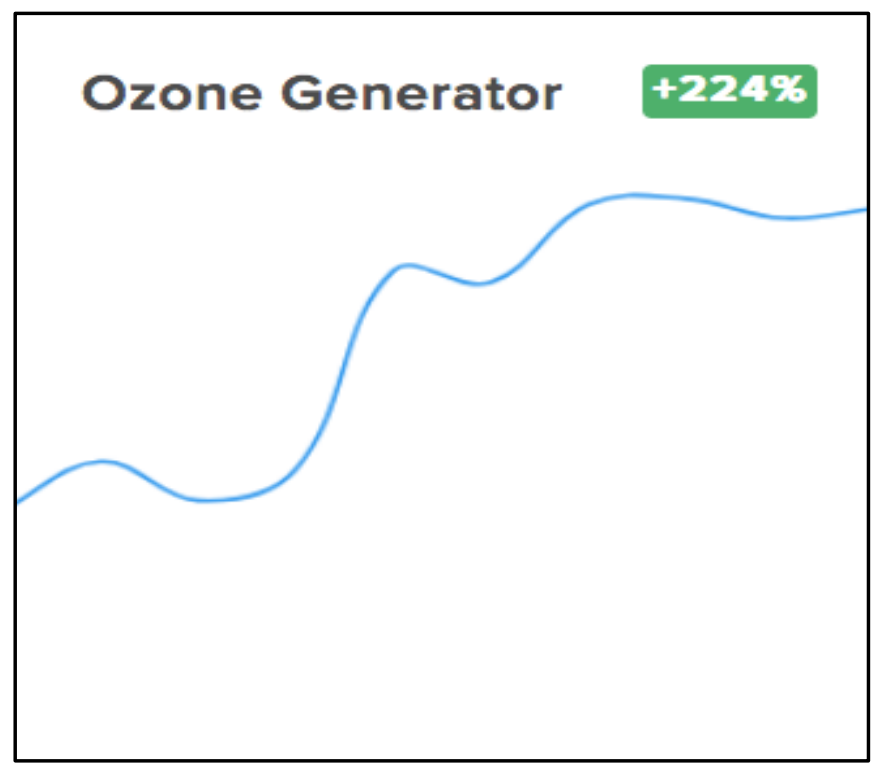

Figure 8. American Consumer Interest Levels in Ozone Generators, March 2020 
Again, this rush to find information on ozone generators during the early days of the coronavirus in the U.S. was driven by both reporting and rumors on how these machines could be employed to fight against - and perhaps even kill - the virus. [35] Ozone sterilization is a proven means used by hospitals to sterilize equipment and have worked on some types of coronaviruses in the past, including the virus that caused SARS during the 2003 epidemic. [36] However, when used improperly, these devices can also "create a wide range of health problems, particularly with the lungs. They can inflame and damage airways and make the lungs more susceptible to infection." [37] The Internet "word of mouth" on ozone generating machines got so bad that the EPA (Environmental Protection Agency) recently had to come out and publicly advise Americans not to use ozone generators as a preventative device for dealing with the coronavirus, as the risks far outweigh any possible rewards! [38]

\subsubsection{Supplements and Drugs}

During the early part of the COVID-19 pandemic in the United States, there was intense interest in existing supplements and even prescription drugs that might prove helpful in preventing against and/or treating the coronavirus. [39] Even the President of the United States, Donald Trump, got in on the action here, helping fuel intense consumer interest levels in Hydroxychloroquine, a long-standing antimalarial drug that quite controversially may - or may not - prove to have some efficacy in treating COVID-19 infection. [40]

And while the political, medical, and scientific debate rages on over the efficacy of Hydroxychloroquine's potential use in treating the coronavirus, the media attention has only served to fuel Americans curiosity in the drug. [41] This is evidenced by the fact that, as can be seen in Figure 9 (American Consumer Interest Levels in Hydroxychloroquine, March 2020)

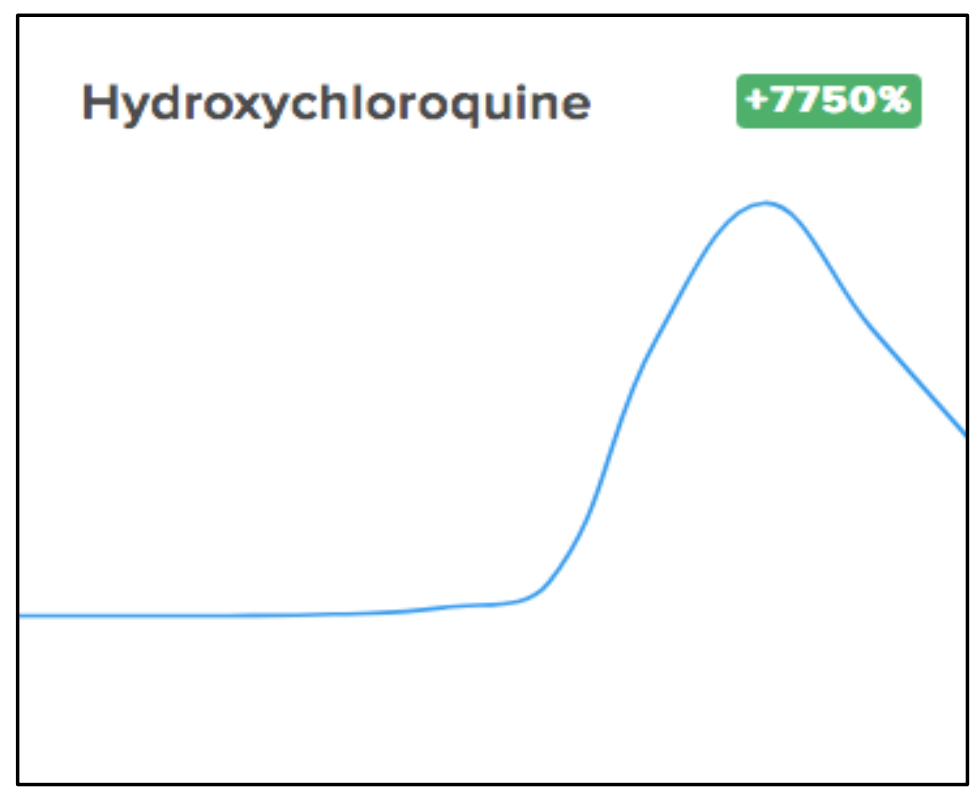

Figure 9. American Consumer Interest Levels in Hydroxychloroquine, March 2020

online consumer interest levels for Hydroxychloroquine jumped by an astonishing $7000 \%$ in March 2020 alone!

The present analysis of the Glimpse consumer interest level data for March 2020 revealed spikes in common supplements such as Vitamin C Gummies (up 532\%) and Zinc Lozenges (up 1250\%), 
International Journal of Managing Information Technology (IJMIT) Vol.12, No.2, May 2020

and even for pantry items like Oregano Oil (up 124\%) that might have some therapeutic/preventative properties. However, much more concerningly, so too did public interest in a whole host of prescription drugs, which, like Hydroxychloroquine, were being touted by some reputable and some not so reputable sources in the media and especially online as possible "cures" for the coronavirus. These were largely for drugs to be used in so-called "off-label use" (which means using an FDA-approved drug for an unapproved use), [42] as well as pharmaceuticals that might not even have been granted approval for use in the United States, including drugs such as:

- Arbidol (up over 13,000\%!) (See Figure 10: American Consumer Interest Levels in Arbidol, March 2020)

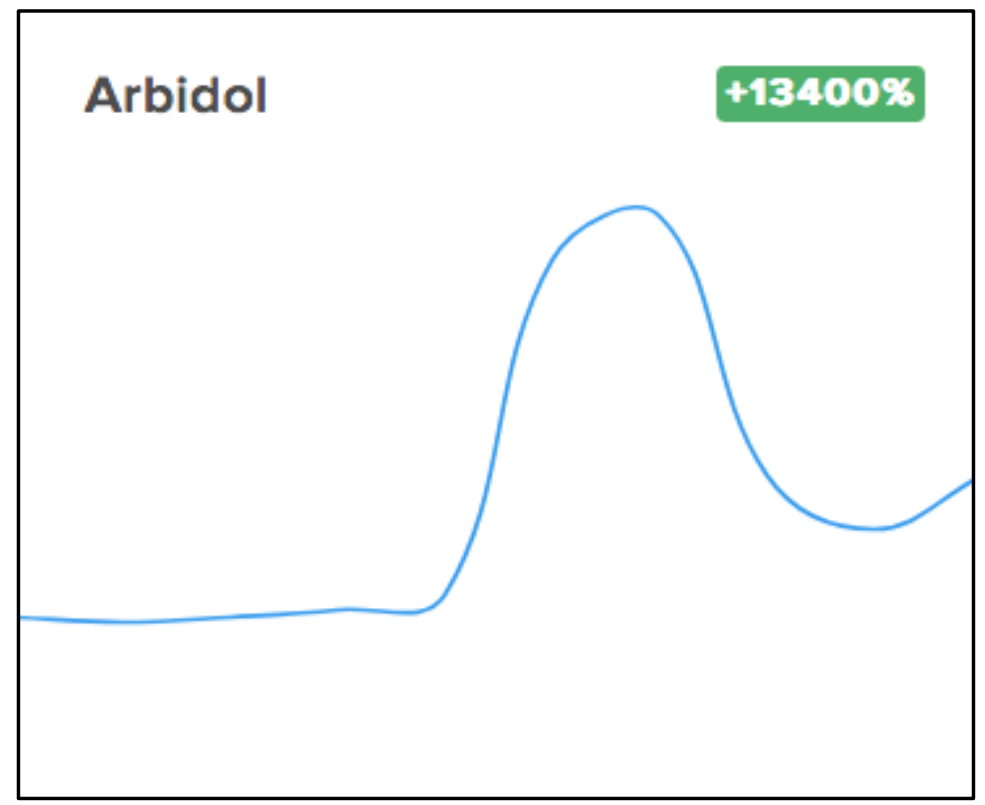

Figure 10. American Consumer Interest Levels in Arbidol, March 2020

- Aplidin (up over 5,000\%!) (See Figure 11: American Consumer Interest Levels in Aplidin, March 2020) 
International Journal of Managing Information Technology (IJMIT) Vol.12, No.2, May 2020

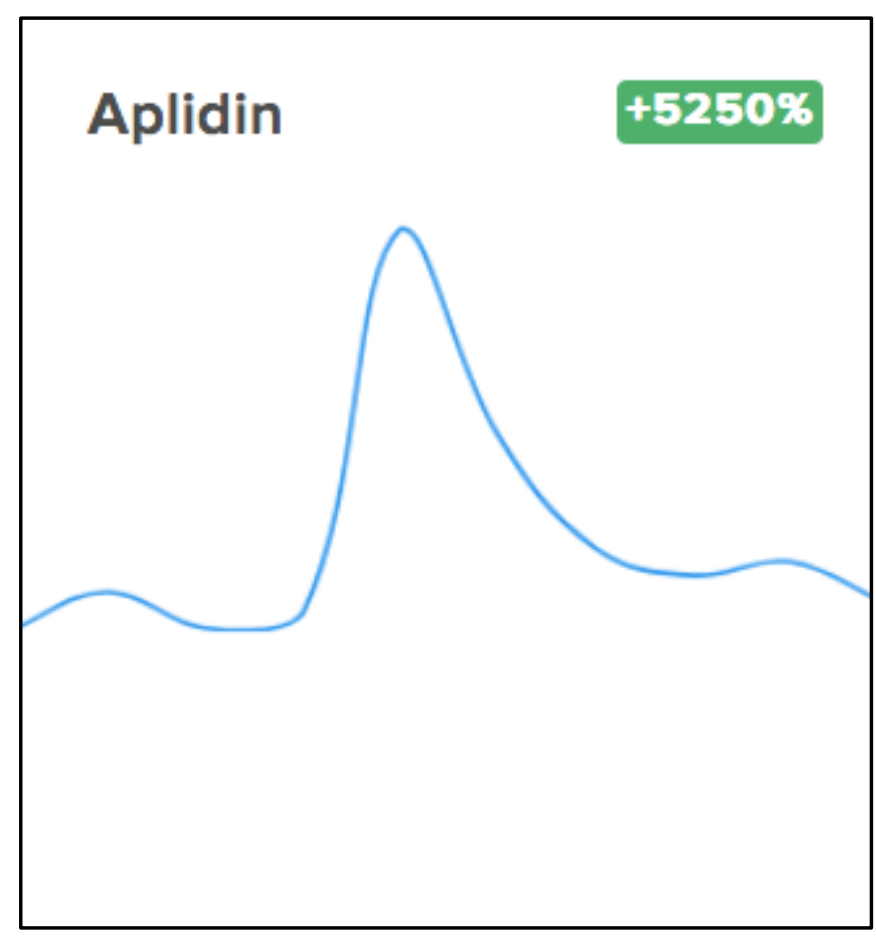

Figure 11. American Consumer Interest Levels in Aplidin, March 2020

- Tocilizumab (up 5,000\%!) (See Figure 12: American Consumer Interest Levels in Tocilizumab, March 2020)

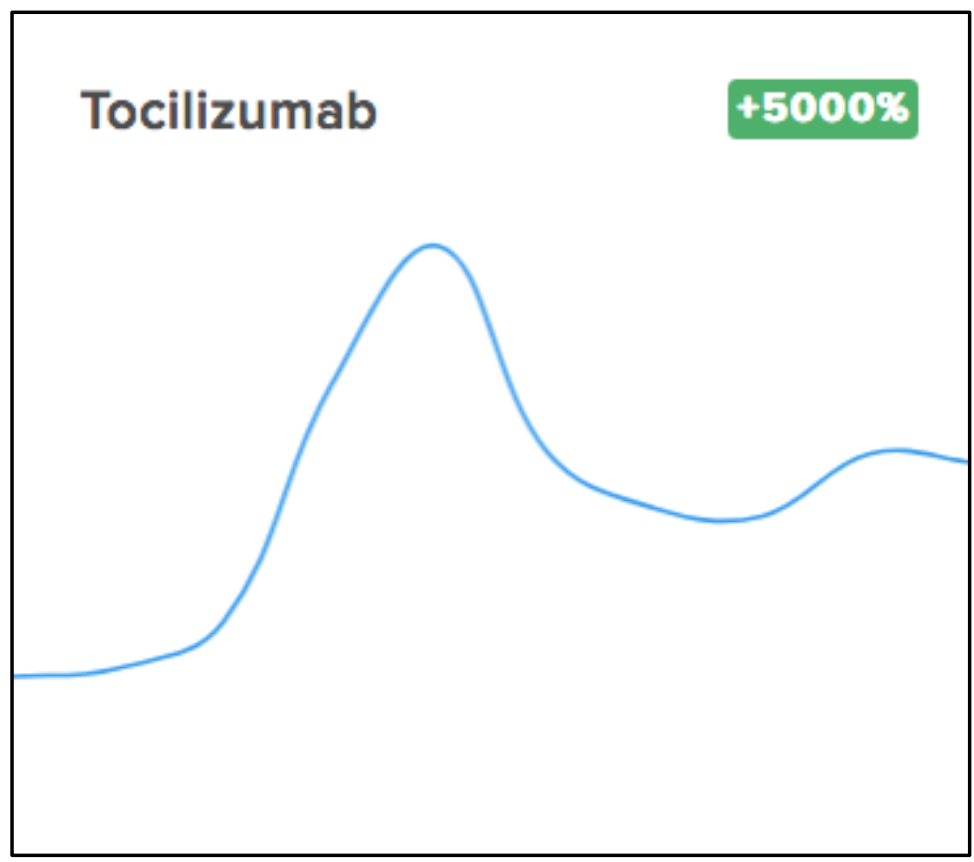

Figure 12. American Consumer Interest Levels in Tocilizumab, March 2020

- Umifenovir (up 4,700\%!) (See Figure 13: American Consumer Interest Levels in Umifenovir, March 2020) 
International Journal of Managing Information Technology (IJMIT) Vol.12, No.2, May 2020

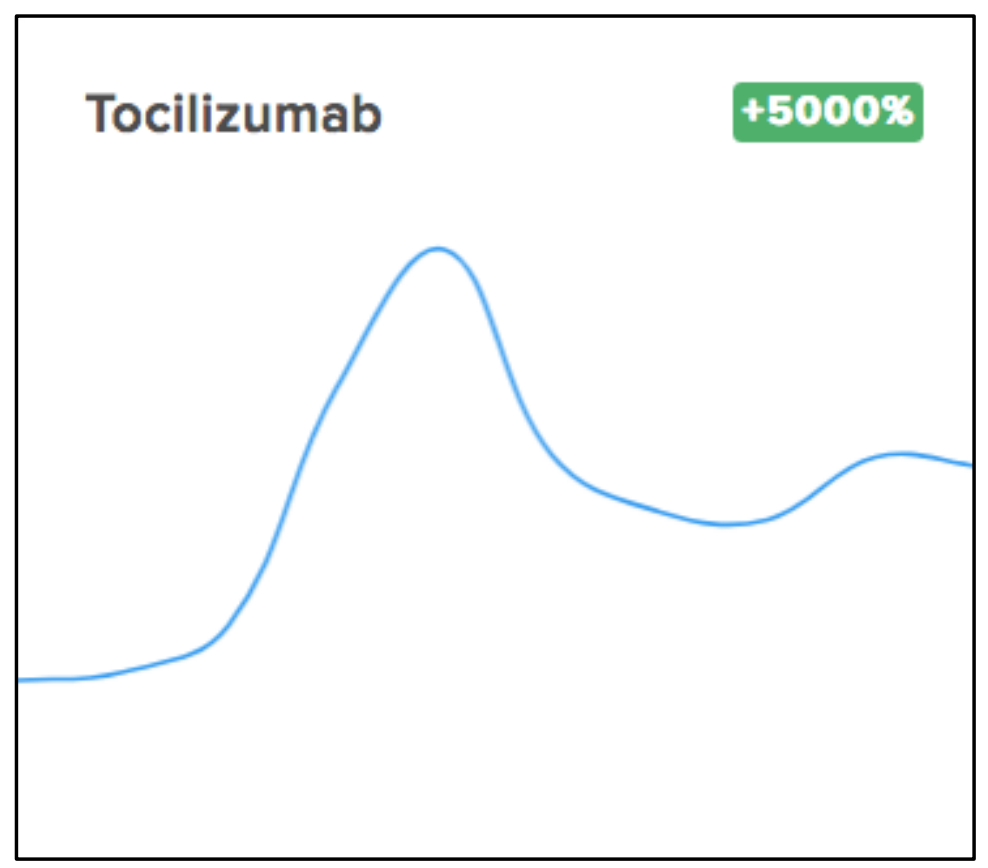

Figure 13. American Consumer Interest Levels in Umifenovir, March 2020

- Plaquenil (up over 3200\%) (See Figure 14: American Consumer Interest Levels in Plaquenil, March 2020)

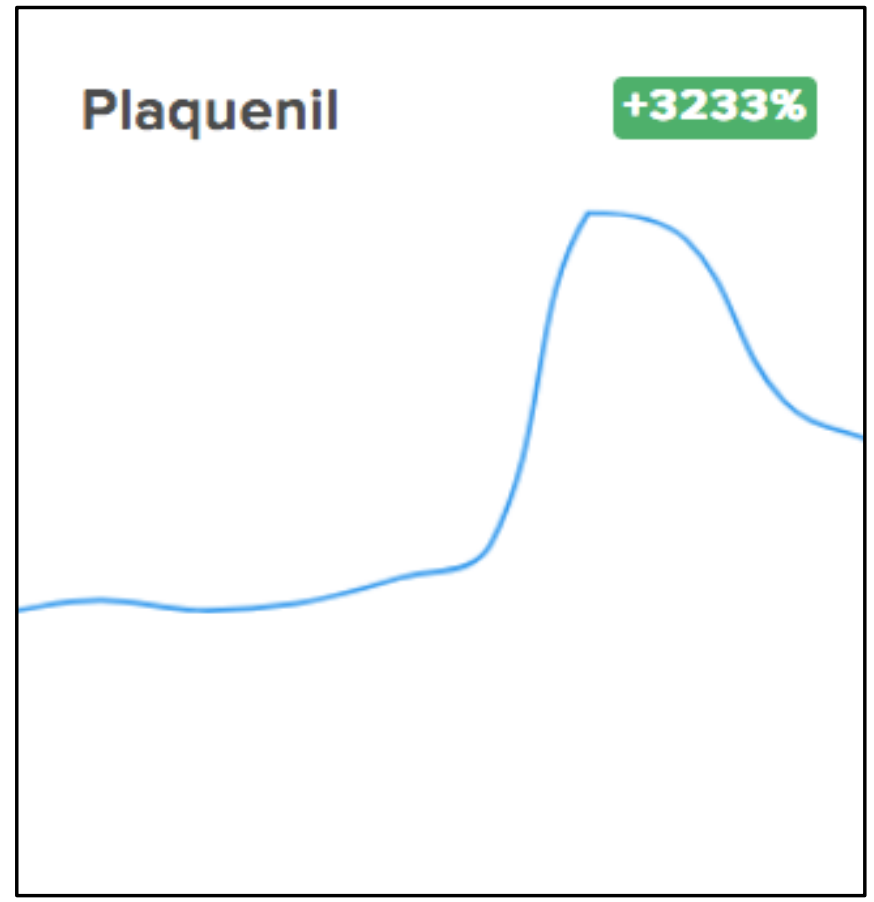

Figure 14. American Consumer Interest Levels in Plaquenil, March 2020

- Kaletra (up over 1700\%) (See Figure 15: American Consumer Interest Levels in Kaletra, March 2020) 


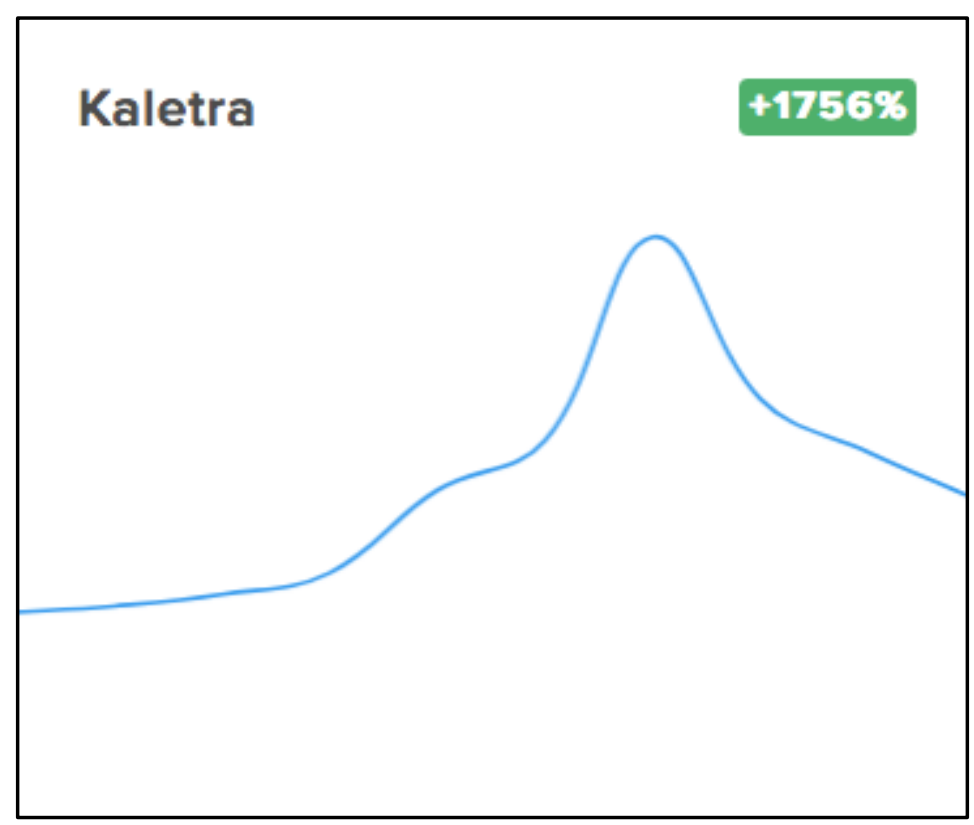

Figure 15. American Consumer Interest Levels in Kaletra, March 2020

- Lopinavir (up almost 1000\%) (See Figure 16: American Consumer Interest Levels in Lopinavir, March 2020)

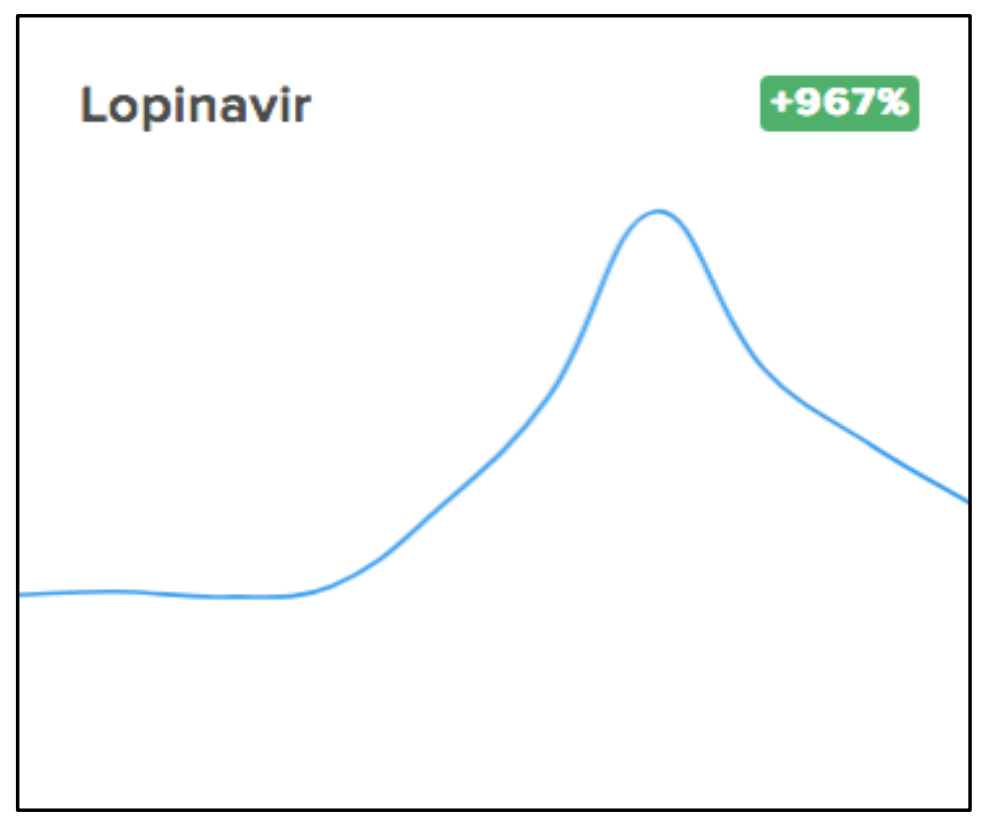

Figure 16. American Consumer Interest Levels in Lopinavir, March 2020

The issues involving the use of prescription drugs off-label and even pharmaceuticals that have not received FDA approval against the coronavirus is a complex subject, one deserving attention far, far beyond what this author can - or should - provide. As the President of the American Medical Association, Dr. Patrice Harris, recently warned: "This is a new virus, and so we should not be promoting any medication or drug for any disease that has not been proven and approved 
by the FDA." [43] This is why this researcher is not going to address the specifics as to why these particular prescription drugs trended during the key month of consumer interest level under review in the present study. To do so might be irresponsible, perhaps even dangerous in light of the risk involved in perpetuating any misinformation that is out there regarding the use of these medications in fighting the coronavirus - even as this article is to read and disseminated months and even years after the 2020 pandemic

One thing is certain however: The consumer interest level in grasping for anything that might help prevent coronavirus infection or work for COVID-19 patients is something that the media, public officials, and yes, pharmaceutical companies should continuously monitor and be in a position to "rapid react" to as trends in online activities develop. "Things" seen on social media, heard in real life, and viewed in online and/or traditional media can quickly form into a vicious, and even dangerous circle and put lives at risk. Therefore, this is an area of Web activity that needs to be closely and continuously monitored. While the monthly data examined here is interesting in terms of looking at macro level movements of American consumer interest levels at this time in retrospect, real-time analysis of such trends will be especially critical for companies and governments to protect public health from misinformation on pharmacological treatment options and availability during the pandemic.

\section{CONCLUSION}

In a time of great uncertainty, from almost every perspective - health, economic, social, familial, etc. - we know that all of us likely made use of the Internet more than ever before in the time of the Great Pandemic of 2020. In this unprecedented time of self-isolation and stay-at-home orders, Americans were online - working, watching, communicating, and yes, searching for medical information online and answers to the questions that all of us have in the midst of the coronavirus outbreak.

And so while this article is a single-shot analysis of one month of data detailing Americans' consumer interest levels at this very unique and unprecedented period of history, it is hoped that this is just the beginning of what will be a very interesting stream of research on how we - both collectively and individually - interact online in an era of profound crisis. As a management professor and "expert" on such marketing and strategic matters, this researcher believes that we will learn a great deal from analyzing how not just Americans, but individuals around the world used the luxury of "having the world at our fingertips" during the coronavirus pandemic of 2020. And maybe, just maybe, we can learn lessons on how to do things better in terms of corporate, governmental and individual/familial reactions in a time of collective crisis. This researcher believes that there is a great deal of insight to be gained from all of this and looks forward to more work on how we can "anticipate the unanticipatable" and do better the next time - or better yet, help to prevent that next time from ever happening! And yes, pandemic marketing analysis and consumer behavior research could prove very helpful in doing so.

\section{ACKNOWLEDGEMENTS}

The author would like to thank Glimpse and CEO Noah Fram-Schwartz for their cooperation in this research project.

\section{REFERENCES}

[1] World Health Organization (2020). Coronavirus Disease (COVID-19) - Events As They Happen. Available at: https://www.who.int/emergencies/diseases/novel-coronavirus-2019/events-as-theyhappen [Accessed 8 April 2020]. 
[2] Bilefsky, D. and Yeginsu, C., 2020. Of 'Covidivorces' And 'Coronababies': Life During A Lockdown. The New York Times. Available at: https://www.nytimes.com/2020/03/27/world/coronavirus-lockdown-relationships.html [Accessed 8 April 2020].

[3] Investopedia. 2020. Black Swan. Available at: https://www.investopedia.com/terms/b/blackswan.asp [Accessed 30 March 2020].

[4] Yong, E., 2020. How The Pandemic Will End. The Atlantic. Available at: https://www.theatlantic.com/health/archive/2020/03/how-will-coronavirus-end/608719/ [Accessed 31 March 2020].

[5] Glimpse. 2020. Glimpse - See The Future Before It Happens. [online] Available at: https://meetglimpse.com [Accessed 1 April 2020].

[6] Centers for Disease Control and Prevention. 2020. Coronavirus Disease 2019 (COVID-19). Available at: https://www.cdc.gov/coronavirus/2019-ncov/index.html [Accessed 10 April 2020].

[7] Mervos, S., Lu, D. and Swales, V., 2020. See Which States And Cities Have Told Residents To Stay At Home. The New York Times. Available at: https://www.nytimes.com/interactive/2020/us/coronavirus-stay-at-home-order.html [Accessed 9 April 2020].

[8] Specktor, B., 2020. Coronavirus: What Is 'Flattening The Curve,' And Will It Work? livescience.com. Available at: https://www.livescience.com/coronavirus-flatten-the-curve.html [Accessed 3 April 2020].

[9] Glimpse. 2020. COVID-19 Trends - See The Pandemic's Consumer Impact. Available at: https://meetglimpse.com/covid19/. [Accessed 2 April 2020].

[10] Galewitz, P., 2020. Telemedicine Surges, Fueled By Coronavirus Fears And Shift In Payment Rules. Kaiser Health News. Available at: https://khn.org/news/telemedicine-surges-fueled-by-coronavirusfears-and-shift-in-payment-rules/. [Accessed 5 April 2020].

[11] Centers for Medicare \& Medicaid Services. 2020. MEDICARE TELEMEDICINE HEALTH CARE PROVIDER FACT SHEET | CMS. Available at: https://www.cms.gov/newsroom/factsheets/medicare-telemedicine-health-care-provider-fact-sheet [Accessed 7 April 2020].

[12] mHealthIntelligence. (2020, March 20). States Move Quickly to Address Coronavirus Pandemic With Telehealth. Available at: https://mhealthintelligence.com/news/states-move-quickly-to-addresscoronavirus-pandemic-with-telehealth [Accessed 5 April 2020]

[13] Khalid, A. (2020, March 20). Telemedicine is facing unprecedented demand in the wake of coronavirus. Quartz. Available at: https://qz.com/1821549/telemedicine-faces-unprecedenteddemand-in-the-wake-of-coronavirus/ [Accessed 9 April 2020]

[14] Khosravi, B. (2020, March 29). Post-Coronavirus, How Telemedicine Could Upend TheHealthcare System. Forbes. Available at: https://www.forbes.com/sites/bijankhosravi/2020/03/29/postcoronavirus-how-telemedicine-could-upend-the-healthcare-system/\#5a2a6fd8d03f [Accessed 8 April 2020]

[15] Lopez, G. (2020, March 27). Why America ran out of protective masks - and what can be done about it. VOX. Available at: https://www.vox.com/policy-and-politics/2020/3/27/21194402/coronavirusmasks-n95-respirators-personal-protective-equipment-ppe [Accessed 5 April 2020] 
International Journal of Managing Information Technology (IJMIT) Vol.12, No.2, May 2020

[16] Page, S. (2020, March 22). When nothing else matters: Coronavirus fuels a thirst for answers, an effort to spin blame. USA Today. Available at: https://www.usatoday.com/story/news/politics/2020/03/22/coronavirus-fuels-thirst-answers-andeffort-spin-blame/2893949001/ [Accessed 5 April 2020]

[17] Jacobs, A., Richtel, M., \& Baker, M. (2020, March 19). 'At War With No Ammo': Doctors Say Shortage of Protective Gear Is Dire. The New York Times. Available at: https://www.nytimes.com/2020/03/19/health/coronavirus-masks-shortage.html [Accessed 30 March 2020]

[18] Sonnemaker, T. (2020, April 7). Healthcare workers are so desperate for face masks they're reusing old ones - here's how you can help get them critical supplies. Business Insider. Available at: https://www.businessinsider.com/how-you-can-help-donate-face-masks-doctors-nurses-coronavirus2020-3 [Accessed 9 April 2020]

[19] Fadel, L. (2020, April 2). Doctors Say Hospitals Are Stopping Them From Wearing Masks. NPR. Available at: https://www.npr.org/2020/04/02/825200206/doctors-say-hospitals-are-stopping-themfrom-wearing-masks [Accessed 8 April 2020]

[20] Hansen, C. (2020, April 3). CDC Advises All Americans to Wear Cloth Masks in Public. USNews.com. Available at: https://www.usnews.com/news/national-news/articles/2020-04-03/cdcadvises-all-americans-to-wear-cloth-masks-in-public [Accessed 9 April 2020]

[21] Friedman, U. (2020, April 3). Face Masks Are In: The West has long stigmatized mask-wearing, unlike many Asian countries, where those who don't wear masks during public-health crises are the ones who are stigmatized. The Atlantic. Available at: https://www.theatlantic.com/politics/archive/2020/04/america-asia-face-mask-coronavirus/609283/ [Accessed 9 April 2020]

[22] Huddleston, T. (2020, March 28). The history of hand sanitizer-how the coronavirus staple went from mechanic shops to consumer shelves. CNBC. Available at: https://www.cnbc.com/2020/03/27/coronavirus-the-history-of-hand-sanitizer-and-why-itsimportant.html [Accessed 1 April 2020]

[23] Ducharme, J. (2020, March 11). Do Cleaning Products and Sanitizers Prevent Coronavirus? Time. Available at: https://time.com/5792362/cleaning-products-coronavirus/ [Accessed 10 April 2020]

[24] Weisbaum, H. (2020, March 25). Many common household cleaning products can kill the coronavirus if you use them properly. NBC News. Available at: https://www.nbcnews.com/better/lifestyle/many-common-household-cleaning-products-can-killcoronavirus-if-you-ncna1160271 [Accessed 9 April 2020]

[25] Brueck, H. (2020, March 12). The 4 definitive coronavirus cleanup tools of doomsday preppers each cost under $\$ 5$ - and actually work. Business Insider. Available at: https://www.businessinsider.com/coronavirus-checklist-what-to-keep-in-your-purse-or-backpack2020-3 [Accessed 26 March 2020]

[26] Guthrie, G. (2020, April 1). Foot traffic at big retailers falls after mad rush for coronavirus-related essentials. Consumer Affairs. Available at: https://www.consumeraffairs.com/news/foot-traffic-atbig-retailers-falls-after-mad-rush-for-coronavirus-related-essentials-040120.html [Accessed 10 April 2020]

[27] Gralish, T. (2020, March 24). Look what coronavirus panic buyers did and didn't buy. The Philadelphia Inquirer. Available at: https://www.inquirer.com/health/coronavirus/coronavirus-panicbuying-food-cleaning-supplies-pictures-20200316.html [Accessed 5 April 2020]

[28] Leiva, C. (2020, March 19). How Long Coronavirus Lives On Clothes, And How To Wash Them. HuffPost. Available at: https://www.huffpost.com/entry/how-long-coronavirus-live-clothingwashing_1_5e724927c5b6eab779409e74 [Accessed 10 April 2020] 
International Journal of Managing Information Technology (IJMIT) Vol.12, No.2, May 2020

[29] Naughton, J. (2020, March 14). Fake news about Covid-19 can be as dangerous as the virus. The Guardian. Available at: https://www.theguardian.com/commentisfree/2020/mar/14/fake-news-aboutcovid-19-can-be-as-dangerous-as-the-virus [Accessed 7 April 2020]

[30] O'Kane, C. (2020, March 12). Televangelist Jim Bakker sued for selling fake coronavirus cure. CBS News. Available at: https://www.cbsnews.com/news/jim-bakker-coronavirus-covid-19-fake-curetelevangelist-sued-by-missouri-symptoms-selling-treatment/ [Accessed 5 April 2020]

[31] Garlich, J. (2020, March 17). No, a silver solution won't cure the coronavirus.PolitiFact. Available at: https://www.politifact.com/factchecks/2020/mar/17/sherill-sellman/no-silver-solution-wont-curecoronavirus/ [Accessed 5 April 2020]

[32] National Institutes of Health (2017, April). Colloidal Silver. Available at: https://www.nccih.nih.gov/health/colloidal-silver [Accessed 6 April 2020]

[33] Khalid, A. (2020, April 5). Pulse oximeters are selling out because of the pandemic. Most people don't need them. Quartz. Available at: https://qz.com/1832464/pulse-oximeters-for-coronavirusunnecessary-but-selling-strong/ [Accessed 6 April 2020]

[34] Taghipour, D. J., \& Anoruo, N. A. (2020, April 3). Should pulse oximeters be used at home to track coronavirus symptoms? Doctors say for most people they aren't needed -- and may even be a bad idea. ABC News. Available at: https://abcnews.go.com/Health/pulse-oximeters-home-trackcoronavirus-symptoms/story?id=69939772 [Accessed 8 April 2020]

[35] Cheung, R. (2020, March 12). Ozone generators and UV light: Will alternative disinfectants work on coronavirus? Quartz. Available at: https://qz.com/1815628/coronavirus-fuels-interest-in-alternativedisinfectants/ [Accessed 8 April 2020]

[36] Loynes, C. (2020, April 8). Does ozone sterilization kill the Coronavirus which causes COVID-19? Aeroequal. Available at: https://www.aeroqual.com/does-ozone-kill-coronavirus-covid-19 [Accessed 9 April 2020]

[37] Oransi. (n.d.). Air Purifiers and Ozone Generators: What You Need to Know. Available at: https://www.oransi.com/page/ozone-air-purifier [Accessed 8 April 2020]

[38] U.S. Environmental Protection Agency (EPA). (2020, March 30). Will an Ozone Generator protect me and my family from COVID-19? Available at: https://www.epa.gov/coronavirus/will-ozonegenerator-protect-me-and-my-family-covid-19 [Accessed 11 April 2020]

[39] Healy, M. (2020, April 3). Malaria drugs aren't the only ones on the shelf that might help coronavirus patients. The Los Angeles Times. Available at: https://www.latimes.com/science/story/2020-0403/existing-drugs-to-treat-coronavirus-covid [Accessed 9 April 2020]

[40] Charles, D. (2020, April 4). FACT CHECK: Premature - Trump Continues To Claim Drug Can Treat Coronavirus. NPR. Available at: https://www.npr.org/sections/coronavirus-liveupdates/2020/04/03/827177623/fact-check-premature-trump-continues-to-claim-drug-can-treatcoronavirus [Accessed 10 April 2020]

[41] Solomon, S. (2020, April 2). Debate Rages as Anti-malaria Drugs Are Rushed for COVID-19 Use. VOA News. Available at: https://www.voanews.com/science-health/coronavirus-outbreak/debaterages-anti-malaria-drugs-are-rushed-covid-19-use [Accessed 6 April 2020]

[42] U.S. Food and Drug Administration. Understanding Unapproved Use of Approved Drugs "Off Label". (2018, February 5). Available at: https://www.fda.gov/patients/learn-about-expanded-accessand-other-treatment-options/understanding-unapproved-use-approved-drugs-label [Accessed 8 April 2020] 
International Journal of Managing Information Technology (IJMIT) Vol.12, No.2, May 2020

[43] Harvey, J. (2020, April 6). AMA President Has A Stark Warning About Trump's Coronavirus Treatment Advice. HuffPost. Available at: https://www.huffpost.com/entry/ama-president-trumphydroxychloroquine_n_5e8a9914c5b6e7d76c663197 [Accessed 11 April 2020] 